\title{
Assistive Devices for Older Adults: A Longitudinal Study of Policy Effectiveness, Santiago, Chile, 2014-2016
}

\author{
Macarena Hirmas-Adauy MPH, Andrea Olea MD MPH, Isabel Matute MPH, Iris Delgado MS, Ximena Aguilera MD MPH, \\ Lucy Poffald MS, Claudia González MPH, Manuel Nájera MD MS, María Inés Gómez MD, Ligia Gallardo, \\ María Teresa Abusleme MS, Jaime Leppe MS, Hernán Mery, Eladio Recabarren, Cristián Massad, Hernán Bustamante MD MBA
}

\begin{abstract}
INTRODUCTION Population aging is a worldwide phenomenon. It is estimated that by 2050 , one of five persons will be aged $\geq 60$ years. In Chile, $15.8 \%$ of the population is now aged $\geq 60$ years, and this figure will reach $30.7 \%$ by 2050 . In 2006 , a national program was implemented to provide assistive devices to older adults aged $\geq 65$ years with limited mobility or difficulty performing activities of daily living. To date, there have been no assessments of the program's effectiveness.
\end{abstract}

OBJECTIVE Assess the effectiveness of an assistive devices policy in Chile on improving functional capacity of older adults aged $\geq 65$ years, and beneficiaries' perceptions of the services received, including changes in their quality of life.

METHODS This was a before-after longitudinal study. A cohort of 309 persons was recruited, consisting of patients who received care at a public hospital in Santiago, Chile during 2014-2015. They were assessed before delivery of assistive devices, then followed for seven months, with repeated evaluations made in their homes. The following indicators were measured: functional capacity (Tinetti scale and Barthel Index); changes in perceived quality of life related to use of assistive devices; and other sociodemographic, clinical and protocolcompliance variables. A longitudinal analysis of before-after progress

\section{INTRODUCTION}

Population aging is a worldwide phenomenon. It is estimated that by 2050 , there will be 2 billion persons aged $\geq 60$ years (22\%).[1] In Chile, this group now represents $15.8 \%$ of the population,[2] and is expected to reach $30.7 \%$ by 2050 .[3] In addition, the percentage of those aged $\geq 80$ years (very old age) in this group will grow substantially.[3,4]

The aging process manifests as declines in physical, mental and psychosocial health, and inability to perform activities of daily living.[5] In Chile, although $94.7 \%$ of persons aged $60-64$ are classed as functionally independent, with only $0.9 \%$ severely dependent; in persons aged $\geq 80$ years these figures change to $60.4 \%$ and $12.9 \%$, respectively.[6] In persons aged $\geq 60$ years, $10.4 \%$ show some cognitive impairment, and $4.5 \%$ have disability-associated cognitive impairment.[7] Functional impairment, along with environmental conditions, can affect life performance and alter gait, resulting in the need for assistive devices (ADs) in some older adults to maintain their independence and autonomy.[8]

IMPORTANCE This study is the first to assess effectiveness of the national assistive devices program for older adults in Chile, a public policy implemented since 2006. was carried out, as well as a description of service delivery and medical followup.

RESULTS Sixty-eight percent of those surveyed were women; median age was 74 years, average schooling was 6 years, and $93 \%$ had low income (monthly income <US\$398). Assistive devices increased independence in activities of daily living, improved mobility and perceived quality of life, and decreased fall risk and pain. One hundred percent felt satisfied with the service received, $91 \%$ were trained in use of the device, and delivery deadlines were met in $83 \%$ of cases, but only $2 \%$ were followed up. One negative aspect is that the program covers only $25 \%$ of estimated need.

CONCLUSIONS This assistive device program helps improve functional capacity and perceived quality of life in vulnerable patients who are able to access it. It addresses a real need and is highly valued by patients. Although delivery schedules were fulfilled, followup care schedules were not.

KEYWORDS Aging, mobility limitation, assistive devices, activities of daily living, health care system, health care reform, quality of life, Chile

In 2006 in Chile, the provision of ADs for persons aged $\geq 65$ years was introduced in the Explicit Health Guarantees Regime (GES) [9] to improve functional abilities. Created in the aftermath of a 2005 health care reform,[9] the GES lists priority health conditions qualifying for access guaranteed by law (legal right to health care), timeliness (specified maximum waiting times for services), financial protection (maximum copay of $20 \%$ ) and quality (accredited providers). Its main objective is to reduce health care disparities for a group of services, in both the public and private healthcare systems.

The Chilean health system is mixed. Public health insurance through a national health fund (FONASA) covers about $80 \%$ of the population with care mainly by providers within the public National Health Services System. FONASA classifies its members in categories A, B, C or D, based on income. Categories A and $B$ are for lowest-income segments ( $\leq$ US $\$ 423$ per month). Another parallel, private health subsystem and a separate health system within the armed forces complete the spectrum of coverage offered to Chileans. Less than $5 \%$ of the Chilean population is not covered by any health insurance system. $[10,11]$

Through its AD program for persons aged $\geq 65$ years, GES ensures provision of canes, walkers and wheelchairs to promote recovery of function, improve gait and stability, and foster independence in activities of daily living.[12] Medical AD prescription is based on a functional assessment using the Barthel Activities 
of Daily Living Index and the Tinetti Falls Risk Scale.[5,12-14] From the time of medical prescription, the legally established period for timely delivery is a maximum of 20 days for canes and 30 days for walkers and wheelchairs. The clinical guidelines specify that all patients and/or caregivers must receive training and be evaluated one month after AD delivery. In addition, further followup must be performed by the patient's primary care provider.[12]

In 2017, the public health system delivered 133,356 ADs to its members throughout the nation, at an estimated annual cost of US $\$ 5.5$ million. The numbers of ADs delivered increased $39 \%$ from 2012 to $2017,[15]$ with an associated $47 \%$ increase in financial costs. $[15,16]$ It is estimated that $19.3 \%$ of older FONASA members need an AD.[16]

This study was carried out with FONASA beneficiaries living within the service area of the Padre Hurtado Hospital (HPH), which belongs to the Southeast Metropolitan Health Service in Santiago, Chile. HPH serves the municipalities of San Ramón, La Pintana and La Granja, and is institutionally accredited in compliance with GES.

At the time of the study, no assessment was available regarding the effect of the GES AD program on recovery of functional capacity, nor had there been any previous study of beneficiaries' perceptions of the delivery process or of changes that ADs had made in their quality of life. For this reason, in 2014, HPH, in conjunction with the National Service for Older Adults, the National Disability Service, and the Epidemiology and Health Policy Center of the Medical School, Clínica Alemana, Universidad del Desarrollo (CEPS-CAS-UDD), began a study with two objectives: to assess effectiveness of the $A D$ provision policy in improving functional capacity in persons aged $\geq 65$, and to understand the care process and members' perceptions of the service they received, as well as resulting changes in their quality of life (QoL).

\section{METHODS}

Study design This before-after longitudinal, analytical observational study involved persons aged $\geq 65$ living in the HPH service area, who participated in the GES AD program and received a cane, walker or wheelchair from September 2014 through July 2015. Each participant was followed over 7 months with 4 assessment points: T0 or baseline, when participants were enrolled and received their $A D$; and $T 1, T 2$ and $T 3$, at 40, 130 and 220 days after enrollment, respectively.

Population and sample size calculation Eligible persons were aged $\geq 65$ years, who were members of FONASA and received their AD through GES at $\mathrm{HPH}$. The size of the universe was estimated at 1645 persons, based on the number of ADs delivered the year before the study (2013). With a repeated sampling design and assumptions of a mean 5-point improvement from baseline to final score for dependence in carrying out activities of daily living (Barthel Index), a 95\% confidence level, $90 \%$ power and expected standard deviation of 20 points at baseline and 15 points at the end, a minimum sample size of 265 persons was estimated to be monitored through study completion. Since older-adult participants were to be assessed 4 times in the 7-month period, an approximate natural attrition rate of $5 \%$ between each measurement was estimated; thus, the study began with 309 persons.

ADs delivered the year before the study to $\mathrm{HPH}$ included wheelchairs $(35 \%)$, canes $(46 \%)$ and walkers $(19 \%)$. For purposes of sample distribution and subsequent analysis, these percentages were adjusted to $30 \%$ for wheelchairs and walkers, and $40 \%$ for canes. Sample size was calculated using the EPIDAT 4.1 epidemiology program, with a paired-sample average comparison design.

Inclusion and exclusion criteria, recruitment Persons aged $\geq 65$ years who received ADs under the GES regime and did not have cognitive impairment (Mini-Mental exam $\geq 14$ points) were included.[5,12] Persons hospitalized at the time of the study, those who received a temporary assistive device, and people diagnosed with dementia were excluded.

Recruitment took place at HPH. Every person who had been prescribed an AD from September 2014 through July 2015 was contacted to request his or her voluntary participation in the study. A Mini-Mental exam was performed to assess exclusion criteria. Participants were invited to enroll based on written informed consent. Enrollment continued until the estimated sample size was reached. A baseline functional assessment (T0) was made at hospital and subsequent assessments (T1, T2, T3) were made in participants' homes.

Variables and data analysis A description of participants was made at the time of enrollment (TO), which included: age in years; sex male/female); indigenous group membership (yes/ no); educational level completed (none/primary education/ secondary school/higher education, including technical, trade, normal schools or university); employment status (active/inactive); health insurance (FONASA A or B/FONASA C or D); participant's monthly income considering wages, pensions and other income; monthly per capita household income, calculated using number of dependent persons; reduced income due to health condition (yes/no); partner status (living with a partner/ not living with a partner); presence of caregiver (has caregiver/ needs caregiver, but does not have/does not need help); chronic diseases due to multiple causes per ICD10; chronic pain (yes/no); fall reported in the previous six months (yes/no); and type of AD delivered (cane, walker, wheelchair, and wheelchair plus another aid).

Percentages were calculated for the above variables, as well as median age and age range. To analyze the number of persons lost to followup, rates were used that took months of observation per person into account. For participants who died, the cumulative mortality rate for the followup period (seven months) and mortality incidence were used, considering the months of observation per person.

To assess effectiveness of the AD provision policy on improvement of functional capacity, the following variables already mentioned above were analyzed according to study objectives: functional capacity, fall frequency, presence of pain and mobility problems. The operationalizing, measurement and analysis of these variables is described below.

Functional capacity Two tools were used. One is the Barthel Index,[5,12-14] which measures capacity to perform ten activities 
of daily living. These activities can be scored as $0,5,10$ or 15 points, depending on degree of independence. With this method, a total score from 0 to 100 is obtained-which will always be a multiple of 5-the higher the score, the greater the independence. Scores are grouped into categories according to dependence levels: $<20$ totally dependent, $20-35$ severely dependent, $40-55$ moderately dependent, $\geq 60$ but $<100$ mildly dependent, and 100 independent (90 if using wheelchair).The second tool applied was the Tinetti scale,[12-14] which measures fall risk with a score of $0-28$. On this scale, the higher the score, the lower the risk. There are 3 risk levels: $<19$ high risk, 19-24 medium risk, and 25-28 low risk. Both variables were analyzed as continuous and categorical variables.

Means and standard deviations of the Barthel and Tinetti scores were calculated for each followup point. In addition, longitudinal analysis of these scores was performed using a General Linear Model for repeated measurements with $p=0.05$ as significance threshold. Categorical analysis for both indices was performed by calculating proportions of participants at each followup point. Dichotomous variables were generated to assess progress from T0 to T3. The Barthel Index was dichotomized as "independent" and "dependent," using a score of 60 as the cutoff point. $[17,18]$ This score classifies those who show "independence" or "mild dependence" on the original index as independent, and those with "moderate dependence," "severe dependence" or "total dependence" as dependent. The Tinetti score was measured for those able to walk at the time of testing, and a score of 18 (upper limit of the high-risk category) was taken as the cutoff point, generating the categories "high fall risk" and "medium and low fall risk." Progress of participants from beginning to end of followup was analyzed using these dichotomous variables.

Moving from dependence to independence or remaining independent were considered a positive course on the Barthel Index, while moving from independence to dependence or remaining dependent were both classified as a negative course. For the Tinetti score, moving from high fall risk to medium or low fall risk or remaining in the medium or low fall risk category were both classified as a positive course, while moving from medium or low risk to high risk, or remaining a high fall risk were both considered a negative course. The McNemar-Bowker test was used to assess the statistical significance of these changes, comparing assessments from T0 to T3 using dichotomous categories, with a significance threshold of $p=0.05$.

Sample size variations were larger in the Tinetti test because of participants lost to followup and exclusion of those unable to walk at T0 or T3, as well as those who received only a wheelchair, since the test did not apply in such cases. The before-after course could not be analyzed for any of these participants, since both measurements were not always available.

Fall frequency Upon recruitment, participants were asked about number of falls in the previous six months, and the proportion of participants reporting falls as well as the total and average number of falls were calculated. Participants were also asked for the number of falls between each followup point. Fall incidence was calculated using observation time per person (months/person). Pain The study considered two variables: "new pain with AD use" and "chronic pain that decreased with $A D$ use." Both are dichoto- mous (yes/no) variables. The presence of pain for more than six months from baseline was considered chronic pain. The proportion of participants in both categories was analyzed.

Mobility problems Upon recruitment and at the last observation point, participants were asked about mobility problems both inside and outside the home, and the number of persons reporting these problems was analyzed. The number of persons reporting fear of falling when leaving home was also studied. The McNemar test was run on contingency tables, with $p<0.05$.

To understand the characteristics of the care process and members' perception of care and changes in their QoL with the AD, data were collected on timeliness and consistency of delivery, training in $A D$ use, monitoring one month after delivery, and followup in primary care. These variables were analyzed according to GES clinical guideline recommendations.

Timeliness of delivery Percentage of participants receiving ADs within the period specified in GES guidelines. For time elapsed, the median number and range of days were calculated.

Consistency of delivery Percentage of participants receiving the same $A D$ prescribed in primary care, and percentage of supplied ADs matching the degree of dependence and fall risk found at the time of recruitment (TO).

Training in use Percentage of participants and/or caregivers who reported having received training at the time of delivery.

Checkup one month after delivery to assess participant $A D$ use and make adjustments Percentage of participants who reported being contacted for checkup one month after AD delivery, as indicated in GES guidelines.

Followup in primary care Percentage of participants who went for their regular primary care checkup and percentage of checkups in which the care provider inquired about participant's AD use. During the first year of the study, we also calculated AD deliveries as a percentage of the total number of FONASA older adults requiring them, according to national estimates (19.3\%). This indicator served as a performance measure of access guarantee.

Satisfaction with care Based on participant declaration, satisfaction at time of delivery (very satisfied/satisfied/unsatisfied/very unsatisfied). Percentage of participants in each category was also calculated.

Perceived quality of life effects A tool designed in 2011 by the National Disability Service (SENADIS) was used to study changes in perceived QoL attributable to AD delivery and use. The tool, based on a questionnaire, had two dimensions: wellbeing (nine questions on wellbeing with $A D$ use in education, employment, free time and leisure activities) and satisfaction (four questions about users' perception of AD related to their performance in daily life, family life, relationships with others, physical condition and emotional state). Questions were answered using the Likert scale, with responses from 1-5, grouped as "negative" (1-3) or "positive" (4-5). For each dimension, a perception was considered positive when more than half the questions received positive responses. Finally, if there was a positive perception in at least one of these two di- 
mensions, this was considered a positive change in perceived AD-attributable QoL. For practical reasons, this measurement was not performed at T2.

Change in perception was also classified as positive or negative, measured from the baseline to the last assessment. Direction was considered positive if participants maintained a positive perception of their QoL, or if QoL changed from negative to positive; and was considered negative if perception remained negative from baseline to last assessment or changed from positive to negative.

Data collection A data collection card was created containing the variables and tools previously mentioned. Before recruitment, the card was tested on 25 persons not included in the sample. Data were collected on site (in hospital and participants' homes) from September 2014 through February 2016 by previously trained kinesiologists. For quality control of data collection, researchers supervised $10 \%$ of participants on site and by telephone, finding no inconsistencies. Data were uploaded to a tablet using the SurveyToGo program[19] and the database was exported to SPSS v25.0, updated and validated weekly.

Ethical aspects The study was approved by the ethics committee of the Southeast Metropolitan Health Service (SSMSO). Participants were invited to enroll based on written informed consent. Participation involved no risk or cost for them, and a conduct protocol was established to provide for situations that might compromise participants' health or safety. Data were de-identified and treated as confidential by the research team.

\section{RESULTS}

Description of participants Contact was made with 542 older adults who had been prescribed an AD, of whom $233(43 \%)$ were excluded due to an abnormal score on the Mini-Mental exam. The remaining 309 were recruited for the study. Forty-two participants (13.6\%) were lost to followup: 20 died, 8 could not be located, 7 moved to other communities, and 7 decided not to continue followup. The final sample size was 267 participants (1954 person-months) of observation. Those who died contributed 43 person-months, and the rest of the lost participants contributed 42 person-months, translating into a $9.7 \%$ loss of observation time per person. The cumulative mortality rate for the followup period was 6.5 per 100 persons, and the mortality incidence was 1.02 per 100 persons per month.

Regarding delivered ADs, 124 participants (40\%) received a cane, $52(17 \%)$ a walker, $70(23 \%)$ a wheelchair, and $63(20 \%)$ a wheelchair plus another AD (cane or walker).

The median age was 74 years (range of 65-99) and 68\% were women. Participants who reported membership in an indigenous group were $6.1 \%$, all Mapuche. Seventy percent reported having completed an elementary or primary level of education; $94 \%$ were not actively employed; and $89 \%$ belonged to the two lowest public health insurance income categories. Concerning personal monthly income, 93\% (284/306) were receiving less than US\$391, and when the number of persons depending on that income was considered, for $72.2 \%$ of cases per capita income was less than US\$156 (Table 1). Participants who stated that their income had been reduced due to their health problem made up $73.8 \%$ (228/309) of the total.

The main chronic conditions reported were: diseases of the circulatory system (88.3\%), musculoskeletal and connective tissue (73.5\%), endocrine, and nutritional and metabolic system $(62.5 \%)$, as well as vision or hearing loss $(61.2 \%)$ (Table 1). Conditions leading to prescription of an AD were: arthritis/arthrosis (218/304, $72 \%)$, altered gait/fall risk $(54 / 304,18 \%)$ and stroke $(33 / 304$, $11 \%$ ). Of the participants, $44.7 \%$ were living with a partner, $74.1 \%$ reported having a caregiver, and $3.6 \%$ needed a caregiver but did not have one.

Table 1: Sociodemographic characteristics, health problems and type of assistive device provided, Santiago, Chile, September 2014-February 2016

\begin{tabular}{|c|c|}
\hline Characteristic & Total \\
\hline Age (median and range in years) $(n=309)$ & $74(65-99)$ \\
\hline \multicolumn{2}{|l|}{$\operatorname{Sex}(n=309)$} \\
\hline Male & $99(32.0 \%)$ \\
\hline Female & $210(68.0 \%)$ \\
\hline \multicolumn{2}{|l|}{ Membership in indigenous group $(n=309)$} \\
\hline Yes & $19(6.1 \%)$ \\
\hline No & $290(93.9 \%)$ \\
\hline \multicolumn{2}{|l|}{ Education level completed $(n=309)$} \\
\hline No schooling & $21(6.8 \%)$ \\
\hline Elementary, primary & $216(69.9 \%)$ \\
\hline Secondary school & $57(18.4 \%)$ \\
\hline $\begin{array}{l}\text { Higher education (technical, trade, normal schools or } \\
\text { university) }\end{array}$ & $15(4.9 \%)$ \\
\hline \multicolumn{2}{|l|}{ Employment status } \\
\hline Active & $290(93.9 \%)$ \\
\hline Inactive & $19(6.1 \%)$ \\
\hline \multicolumn{2}{|l|}{ Health insurance $(n=309)$} \\
\hline FONASA A or B & $275(89.0 \%)$ \\
\hline FONASA C or D & $34(11.0 \%)$ \\
\hline \multicolumn{2}{|l|}{ Monthly per capita household income $(n=306)$} \\
\hline$<$ US\$156 & $221(72.2 \%)$ \\
\hline$\geq$ US\$156 or more & $85(27.8 \%)$ \\
\hline \multicolumn{2}{|l|}{ Partner status $(n=309)$} \\
\hline Living with a partner & $138(44.7 \%)$ \\
\hline Not living with a partner & $171(55.3 \%)$ \\
\hline \multicolumn{2}{|l|}{ Presence of caregiver $(n=309)$} \\
\hline Has caregiver & $229(74.1 \%)$ \\
\hline Needs caregiver, but does not have & $11(3.6 \%)$ \\
\hline Does not need help & $69(22.3 \%)$ \\
\hline \multicolumn{2}{|l|}{ Chronic condition or disease $(n=309)$} \\
\hline Circulatory system & $273(88.3 \%)$ \\
\hline Musculoskeletal and connective tissue system & $227(73.5 \%)$ \\
\hline Endocrine, nutritional and metabolic & $193(62.5 \%)$ \\
\hline Vision or hearing loss & $189(61.2 \%)$ \\
\hline Mental and behavioral disorders & $75(24.3 \%)$ \\
\hline Respiratory system & $73(23.6 \%)$ \\
\hline Genitourinary system & $33(10.7 \%)$ \\
\hline Neoplasms & $32(10.4 \%)$ \\
\hline Nervous system & $25(8.1 \%)$ \\
\hline Digestive system & $21(6.8 \%)$ \\
\hline \multicolumn{2}{|l|}{ Type of assistive device delivered ( $n=309$ ) } \\
\hline Cane (1 or 2$)$ & $124(40 \%)$ \\
\hline Walker & $52(17 \%)$ \\
\hline Wheelchair & $70(23 \%)$ \\
\hline Wheelchair plus another aid & $63(20 \%)$ \\
\hline
\end{tabular}


Assessment of $A D$ policy effectiveness on improved functional capacity, fall frequency, presence of pain and mobility problems The dependence-level score improved significantly during followup, from 79.7 at T0 to 84.7 at T3 ( $<<0.001$ ) (Table 2), showing a positive course in 252 of 267 participants assessed, representing $94.4 \%$ ( $p=$ 0.005 ) (untabulated data). The dependence profile also showed an increase in percentage of independent persons.

At baseline, 173 participants (56\%) reported having fallen in the prior 6 months, with a total of 510 falls (averaging 2.9 per person). This is equivalent to an incidence of 27.5 falls per 100 personmonths. During the 7 months of followup, incidence was 4.8 falls per 100 person-months, representing an approximate fivefold decrease (untabulated data).

Although the mean fall-risk score increased during followup from 19.4 at T0 to 20.4 at T3, the variation was not statistically significant $(p=0.091$ ) (Table 2$)$. The fall-risk profile from T0 to T3 showed a positive course in 85 of the 116 participants assessed, or $73.3 \%(p=0.007)$ (untabulated data).

Concerning pain, at baseline $49.2 \%$ of participants mentioned chronic pain that had lasted more than 6 months. At final followup, $65.8 \%$ reported this pain had decreased with AD use (Table 3 ). On the other hand, approximately 14\% (T1: 38/277; T2: 27/242; T3: $33 / 218$ ) indicated that AD use caused them pain that they did not have previously.

With respect to mobility, a significant decrease was noted in percentage of participants who reported mobility problems at home (the same trend occurs with fear of falling outside the home). There was no significant decrease for persons reporting mobility problems outside the home (Table 3 ).

Table 2: Functional dependence and fall risk at followup points, Santiago, Chile, September 2014-February 2016

\begin{tabular}{|c|c|c|c|c|}
\hline Followup point & TO & T1 & T2 & T3 \\
\hline $\begin{array}{l}\text { Severity level } \\
\text { (degree of dependence) }\end{array}$ & n (\%) & n (\%) & n (\%) & n (\%) \\
\hline Number of cases & 309 & 296 & 276 & 267 \\
\hline Totally dependent & $\begin{array}{r}3 \\
(1.0)\end{array}$ & $\begin{array}{r}4 \\
(1.4)\end{array}$ & 0 & 0 \\
\hline Severely dependent & $\begin{array}{r}11 \\
(3.6)\end{array}$ & $\begin{array}{r}9 \\
(3.0)\end{array}$ & $\begin{array}{r}7 \\
(2.5)\end{array}$ & $\begin{array}{r}7 \\
(2.6)\end{array}$ \\
\hline Moderately dependent & $\begin{array}{r}32 \\
(10.4)\end{array}$ & $\begin{array}{r}14 \\
(4.7)\end{array}$ & $\begin{array}{r}9 \\
(3.3)\end{array}$ & $\begin{array}{r}8 \\
(3.0)\end{array}$ \\
\hline Mildly dependent & $\begin{array}{r}199 \\
(64.4)\end{array}$ & $\begin{array}{r}195 \\
(65.9)\end{array}$ & $\begin{array}{r}166 \\
(60.1)\end{array}$ & $\begin{array}{r}152 \\
(56.9)\end{array}$ \\
\hline Independent & $\begin{array}{r}64 \\
(20.7)\end{array}$ & $\begin{array}{r}74 \\
(25.0)\end{array}$ & $\begin{array}{r}94 \\
(34.1)\end{array}$ & $\begin{array}{r}100 \\
(37.5)\end{array}$ \\
\hline Average (SD) & $\begin{array}{r}79.7 \\
(\mathrm{SD} 17.7)\end{array}$ & $\begin{array}{r}82.3 \\
(S D 16.6)\end{array}$ & $\begin{array}{r}84.3 \\
(\mathrm{SD} 15.8)\end{array}$ & $\begin{array}{r}84.7 \\
(\mathrm{SD} 16.1)\end{array}$ \\
\hline Fall risk ${ }^{a}$ & n (\%) & n (\%) & n (\%) & n (\%) \\
\hline Number of cases & 172 & 183 & 156 & 142 \\
\hline High risk & $\begin{array}{r}72 \\
(41.9)\end{array}$ & $\begin{array}{r}79 \\
(43.2)\end{array}$ & $\begin{array}{r}65 \\
(41.7)\end{array}$ & $\begin{array}{r}50 \\
(35.2)\end{array}$ \\
\hline Medium risk & $\begin{array}{r}80 \\
(46.5)\end{array}$ & $\begin{array}{r}97 \\
(53.0)\end{array}$ & $\begin{array}{r}80 \\
(51.3)\end{array}$ & $\begin{array}{r}79 \\
(55.6)\end{array}$ \\
\hline Low risk & $\begin{array}{r}20 \\
(11.6)\end{array}$ & $\begin{array}{r}7 \\
(3.8)\end{array}$ & $\begin{array}{r}11 \\
(7.1)\end{array}$ & $\begin{array}{r}13 \\
(9.2)\end{array}$ \\
\hline Average (SD) & $\begin{array}{r}19.4 \\
(\mathrm{SD} 5.32)\end{array}$ & $\begin{array}{r}19.8 \\
(S D 4.04)\end{array}$ & $\begin{array}{r}19.9 \\
(\mathrm{SD} 4.08)\end{array}$ & $\begin{array}{r}20.4 \\
(\mathrm{SD} 4.49)\end{array}$ \\
\hline
\end{tabular}

aThose with wheelchairs excluded, since Tinetti does not apply in such cases.
Table 3: Pain, mobility problems and fear of falling at followup after assistive device use, Santiago, Chile, September 2014February 2016

\begin{tabular}{|c|c|c|c|}
\hline Followup point & TO & $\mathrm{T} 3$ & $p$ value \\
\hline \multicolumn{4}{|l|}{ Chronic pain } \\
\hline $\begin{array}{l}\text { Persons reporting } \\
\text { chronic pain at start }\end{array}$ & $152 / 309(49.2 \%)$ & $\mathrm{N} / \mathrm{A}$ & $\mathrm{N} / \mathrm{A}$ \\
\hline $\begin{array}{l}\text { Persons reporting } \\
\text { decreased chronic } \\
\text { pain with } A D \text { use } \\
\text { at followup }\end{array}$ & N/A & $100 / 152(65.8 \%)$ & N/A \\
\hline \multicolumn{4}{|l|}{ Mobility problems } \\
\hline Inside the home & $49 / 214(22.9 \%)$ & $19 / 214(8.9 \%)$ & $<0.001$ \\
\hline Outside the home & $53 / 152(34.8 \%)$ & $39 / 152(25.7 \%)$ & 0.059 \\
\hline \multicolumn{4}{|l|}{ Fear of falling } \\
\hline $\begin{array}{l}\text { Fear of falling if } \\
\text { leaving home }\end{array}$ & $151 / 177(85.3 \%)$ & $65 / 177(36.7 \%)$ & $<0.001$ \\
\hline D: assistive device & N/A not ap & & \\
\hline
\end{tabular}

The care process and participant perception of changes in their lives attributable to AD use Timely delivery guarantee was met for $83 \%(256 / 309)$ of participants. A second AD was prescribed during followup for 41 participants. For these persons, the timely delivery guarantee was met in $80.5 \%$ (33/41) of cases.

Of total participants who received an $A D, 87.4 \%$ were using the one prescribed in primary care (Table 4 ). In the remaining $12.6 \%$ (39/309), the AD was changed by the kinesiologist after assessment at time of delivery. When type of AD provided was studied according to degree of dependence assessed at T0, it was noted that $100 \%$ of persons with total or severe dependence (14) received a walker or wheelchair. Regarding fall risk at time of delivery, $79.1 \%(159 / 201)$ of those at high risk or who were unable to walk received a walker or wheelchair.

Most participants (90.9\%) were trained at baseline in AD use (Table 4). Participants who received wheelchairs represented $75 \%$ of those who received no training (28/309). Of the caregivers who accompanied participants during AD delivery, 85.8\% (205/239) were taught how to use and adjust it.

According to participant reports, only $2.3 \%$ were contacted by their primary care provider for a checkup appointment one month after AD delivery (Table 4), and of those who received a new $A D$ due to the kinesiologist's prescription, none were contacted for a checkup appointment. Concerning followup in primary care, $92 \%(285 / 309)$ of participants went to a primary care checkup during the study period, and in $46.3 \%$ of these checkups, the care provider inquired about their use of the $A D$ (Table 4).

Perception of care and change in quality of life At the time of delivery, all participants (309) were satisfied or very satisfied with the care provided both during and prior to delivery.

Percentage of participants who positively described their quality of life increased during followup (Figure 1). From T0 to T3, a positive change occurred in 159 (59.6\%) of the 267 persons assessed (untabulated data). Differences in the total number of those assessed at each followup point are due to participants lost to followup. Those who showed a positive change in ability 
to perform activities of daily living also had improved quality of life $(61.1 \% ; 154 / 252)$. A similar improvement $(80 \%$; $68 / 85)$ occurred in those who showed a positive change in fall risk (untabulated data).

Table 4: Care process for use of assistive devices, Santiago, Chile, September 2014-February 2016

\begin{tabular}{l|r}
\hline Characteristic & Total \\
\hline Timely delivery guarantee met $(n=309)$ & $256(83.0 \%)$ \\
\hline Prescribed device delivered $(n=309)$ & $270(87.4 \%)$ \\
\hline Training in use $(n=309)$ & $281(90.9 \%)$ \\
\hline One-month followup $(n=309)$ & $7(2.3 \%)$ \\
\hline Followup at primary care level $(n=285)$ & $132(46.3 \%)$
\end{tabular}

Figure 1: Change in perceived quality of life at followup points after use of assistive devices, Santiago, Chile, September 2014-February 2016*

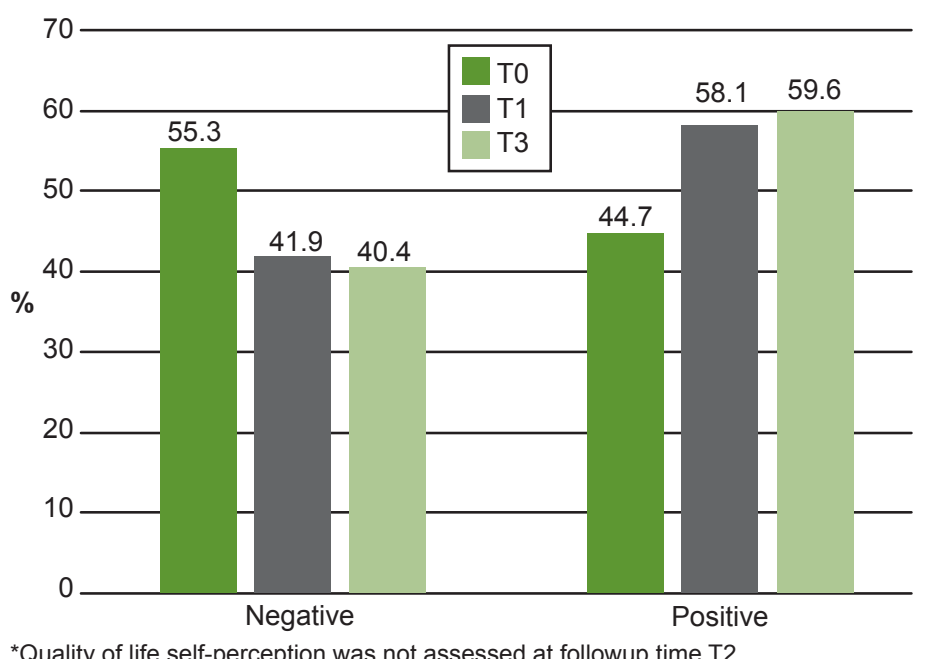

\section{DISCUSSION}

The study shows outcomes of a public policy in a population at risk due to advanced age, lower socioeconomic status and comorbidities. It confirms that for those who accessed the program, the GES regime fosters recovery of functional capacity and improved performance of daily living activities, reduction of fall risk, and better perceived QoL. In 2014, of a total 6756 persons who required an AD according to public insurance estimates, only 1686 ADs were delivered. This means that the program can meet only $25 \%$ of the estimated need of its intended beneficiaries aged $\geq 65$.[20]

Concerning the GES regime's other legally guaranteed standards, timeliness is being met in $83 \%$ of cases. It is important that ADs be delivered as soon as possible, since this leads to better health outcomes.[21-23] The financial protection and quality standards are being met, since the ADs are free for this population group and the hospital has institutional accreditation.

Followup and subsequent monitoring were poor. According to GES clinical guidelines, all patients must be assessed one month after $A D$ delivery and receive subsequent followup in primary care. Only $2 \%$ of study participants received a primary care checkup one month after AD delivery, and fewer than half of those who go for regular health checkups were asked by the attending health care professional about aspects related to their AD. Since these are high-risk individuals, especially those with progressive cognitive impairment or pre-existing mental health conditions, followup is especially important and should meet GES guideline specifications. Such followup allows providers to identify new needs, assess patient experiences with the $A D$, understand the context in which the device is used, and make necessary adjustments. $[12,24-27]$ To address this, a budget for followup activity should be built into the program.

More than half of participants in our study who received an $A D$ reported falls in the previous six months. This percentage is higher than that reported by Iñaki, who predicted $30 \%-40 \%$ of those aged $\geq 65$ will fall at least once a year.[28] Our percentage is also higher than the fall prevalence level of $33.3 \%$ reported by Silva for the 6 months preceding that study.[29] This finding should be duly considered, since falls contribute to higher morbidity and mortality rates, increased health care costs, loss of mobility and independence, general health declines and greater need for long-term care.

In Chile, it has been estimated that one-third of persons aged $\geq 65$ years living at home will suffer a fall during the course of a year. This estimate increases to $50 \%$ for persons living in institutions and those aged $\geq 80$ years. [30] Thus, the AD provision program assessed in this study represents a preventive public policy that makes a major contribution, allowing older adults to avoid falls and live longer in better health.

One surprising finding is the increase in participants with a fall risk 40 days after AD delivery. This may be related to how long it takes them to learn optimal use of the AD. Although there are few mentions in the literature of a specific learning period, experts report that adaptation should take about one month with proper training and followup, which participants in this study did not receive.[31] The eight-week study by Leving[31] in older adults using wheelchairs describes a rapid improvement in use after three weeks of guided training followed by a lesser but sustained improvement after four weeks, compared to a control group without training. Other studies of wheelchair and cane users report shorter times, but with intensive weekly training.[32,33]

The precarious social and economic circumstances of the study population make participants especially vulnerable, since they live in communities exhibiting many indicators of decay. Difficult living conditions in addition to poor health status could explain why fewer than half the participants had a positive outlook on their quality of life at the beginning of the study; however, this improved substantially after $A D$ delivery.

This improvement is still below that found in Chile's 2013 National Socioeconomic Description Survey, which included questions on life satisfaction,[34] and in which $65.8 \%$ of older persons stated that they were completely or highly satisfied with their lives. This figure is consistent with findings of the National Survey on Quality of Life in Old Age, in which $63 \%$ indicated that they were satisfied or very satisfied.[35]

Another finding that underscores the importance of the surrounding environment for QoL are problems with mobility outside the home, which did not improve after AD delivery. Comprehensive, intersectoral policies need to be implemented to accommodate 
aging. These policies should consider safe and "aging-friendly" physical and social environments; allow participation by all stakeholders; involve older adults in policy formulation, development, and implementation; and address the inequalities that affect their health.[8,21,36,37]

Those who had better functional capacity at the beginning of the study significantly improved their independence in performing daily living activities, decreased their fall risk, and improved their perceived QoL. This merits consideration for implementing proactive early-needs surveys and timely AD delivery. Both selfreliance and independence in performing daily activities as well as low fall risk are associated with better perceived quality of life. In this study, those who reported a decrease in their dependence level regarding daily living activities and fall risk also reported significantly improved QoL. Similar findings have been reported in international and national studies relating different dimensions of health to QoL.[38-44]

Although it was not among the study objectives, a collateral finding with implications for public policy was the high percentage of persons with cognitive impairment. The 2017 National Health Survey reported cognitive impairment in $16.9 \%$ of older adults with low educational level.[45] In the recruitment process for this study, the rate was 2.5 times higher $(42 \%)$. This was a limitation of the study, since the research protocol excluded these patients and as a result, no information was obtained from this group. This high percentage of cognitive impairment reinforces the need for followup with systematic checkups after $A D$ delivery.

As in all longitudinal designs, some participants were lost to followup in this study, although the number was lower than predicted.

\section{CONCLUSIONS}

The results confirm that the GES assistive device program addresses a real need in older adults, especially in the most vulnerable, and is highly valued by them. After AD delivery, perceived QoL and independence for performing daily living activities improved and fall risk decreased. This policy has proven to be an important benefit for older adults and is in line with recommendations for implementation of comprehensive policies on aging that can meet the needs of this population. It is important to conduct periodic GES outcome evaluations, and to identify and address the causes of low access and coverage.

\section{ACKNOWLEDGMENTS}

The authors thank the participating older adults and their families; the municipalities and primary healthcare facilities; Hogar Alemán; Fundación Las Rosas; and the professionals who worked on various study phases: physical therapists Marisol Salgado, Jennifer Lara, Mariela Rojas, Martín Arriagada and Ivonne Morales; engineer Sergio Maass; and Dr Andrea Slachevsky. We are also grateful to Carla Castillo-Laborde, Armando Peruga, Jairo Vanegas and Óscar Urrejola for their collaboration in preparing this paper. -1 -

\section{REFERENCES}

1. World Health Organization. Envejecimiento y ciclo de vida. Datos interesantes acerca de envejecimiento [Internet]. Geneva: World Health Organization; 2018 [cited 2018 Nov 26]. Available from: http://www.who.int/ageing/about/age ing_life_course/es/. Spanish.

2. National Institute of Statistics (CL). País y regiones total: Actualización población 2002-2012 y proyecciones 2013-2020 [Internet]. 2017 [cited 2018 Jan 25]. Available from: http://www.ine.cl/ estadisticas/demograficas-y-vitales. Spanish.

3. United Nations Economic Commission for Latin America and the Caribbean. División de Población (ECLAC). Estimaciones y proyecciones de población total, urbana y rural, y económicamente activa. América Latina - Revisión 2017 [Internet]. Puerto España (TT): United Nations Economic Commission for Latin America and the Caribbean. División de Población; 2017 [cited 2018 Jan 25]. Available from: https://www.cepal .org/es/temas/proyecciones-demograficas/esti maciones-proyecciones-poblacion-total-urbana -rural-economicamente-activa. Spanish.

4. Berrío Valencia MI. Envejecimiento de la población: un reto para la salud pública. Rev Colomb Anestesiol [Internet]. 2012 [cited 2016 Aug 4];40(3):192-4. Available from: http://www.scielo org.co/pdf/rca/v40n3/v40n3a05.pdf. Spanish.

5. Muñoz Silva C, Rojas Orellana P, Marzuca G. Criterios de valoración geriátrica integral en adultos mayores con dependencia moderada y severa en Centros de Atención Primaria en Chile. Rev Médica Chile [Internet]. 2015 [cited 2018 Nov 29];143(5):612-8. Available from: http://www.sci elo.cl/scielo.php?script=sci_arttext\&pid=S0034 $-98872015000500009 \&$ Ing $=e s \& n r m=i s o \&$ tlng =es. Spanish.

6. Ministry of Social Development (CL). Encuesta de Caracterización Socioeconómica - CASEN 2015 [Internet]. Santiago de Chile: Ministry of Social Development (CL); 2016 [cited 2018 Aug 15]. Available from: http://observatorio.ministerio desarrollosocial.gob.cl/casen-multidimensional/ casen/casen_2015.php. Spanish.

7. Ministry of Health (CL). Encuesta Nacional de Salud. Chile 2009-2010. Resultados [Internet]. Santiago de Chile: Ministry of Health (CL); 2010 [cited 2019 Jan 10]. Available from: https://www.minsal.cl/portal/url/item/bcb03d7b c28b64dfe040010165012d23.pdf. Spanish.

8. World Health Organization; World Bank. Informe Mundial sobre la Discapacidad [Internet]. Geneva: World Health Organization; 2011 [cited 2019 Jan 10]. Available from: https://www.who.int/dis abilities/world report/2011/es/. Spanish.

9. Ministry of Health (CL). Establece un régimen de garantías en salud. Ley 19966 [Internet]. Santiago de Chile: Ministry of Health (CL); 2004 [cited 2018 Jan 5]. Available from: https://www.leychile $. c l / N ? i=229834 \& f=2004-09-03 \& p=$. Spanish

10. Castillo-Laborde C, Aguilera-Sanhueza $X$, Hirmas-Adauy M, Matute I, Delgado-Becerra I, Nájera-De Ferrari $M$, et al. Health insurance scheme performance and effects on health and health inequalities in Chile. MEDICC Rev [Internet]. 2017 Apr-Jul [cited 2018 Jan 25];19(23):57-64. Available from: http://mediccreview .org/wp-content/uploads/2018/04/mr_591.pdf

11. Aguilera $X$, Castillo-Laborde $C$, Nájera-De Ferrari M, Delgado I, Ibañez C. Monitoring and evaluating progress towards Universal Health Coverage in Chile. PLoS Med [Internet]. 2014 Sep 22 [cited 2018 Jan 25];11(9). Available from: http://dx.plos .org/10.1371/journal.pmed.1001676

12. Ministry of Health (CL). Guía Clínica 2010 Guía Clínica órtesis (o ayudas técnicas) para personas mayores de 65 años y más [Internet]. Santiago de Chile: Ministry of Health (CL); 2010 [cited 2018 Dec 21]. 48 p. Available from: http://www.bibliotecaminsal.cl/wp/wp-content/up loads/2016/04/rtesis.pdf. Spanish.

13. Ministry of Health (CL). Manual de Geriatría para Médicos [Internet]. Santiago de Chile: Min- istry of Health (CL); 2018 [cited 2019 Jan 5]. 427 p. Available from: https://drive.google.com/ file/d/1Dr8WyGIBqrTfbq_q1MfH_oyGjnBRG6OE/ view?fbclid=IwAR2JY E8Th3fsMAmjeTUxf1KPE JiJuupMnj2Fdgef 1g5u-1gnvKtmhPISY. Spanish.

14. Azocar Valenzuela MJ, Mohor Valentino C, Rioja Ponce R, Vargas Leyton M. Estándares de calidad para establecimientos de larga estadía para adultos mayores. Protocolos SENAMA 2016 [Internet]. Santiago de Chile: Ministry of Social Development (CL); 2016 [cited 2018 Jan 5]. 395 p. Available from: http://www.senama.gob.cl/storage/docs/Es tandares Calidad-ELEAM.pdf. Spanish.

15. Statistics and Information Department (CL). Entrega de ayudas técnicas GES a personas de 65 y más años en Chile, años 2012 a 2017 [Internet]. Santiago de Chile: Ministry of Health (CL); 2018 [cite 2018 Dec 20]. Available from: http://www.supersalud.gob.cl/difusion/665/w3 -article-610.html. Spanish.

16. Institute of Health Administration, School of Economy and Businessd (CL). Estudio de verificación del costo esperado individual promedio por beneficiario del conjunto priorizado de problemas de salud con Garantías Explícitas - 2015 [Internet]. Santiago de Chile: Institute of Health Administration; 2015 [cited 2018 Jul 24]. Available from: https://biblioteca.digital .gob.cl/handle/123456789/2328. Spanish.

17. McDowell I. Physical Disability and Handicap. In: Measuring Health - a Guide to Rating Scales and Questionnaires. 3rd ed. Vol 33. New York: Oxford University Press; 2006. 208 p.

18. Trigás-Ferrín M, Ferreira-González L, MeiijideMíguez $\mathrm{H}$. Escalas de valoración funcional en el anciano. Galicia Clin [Internet]. 2011 [cited 2018 Jan 29];72(1):11-6. Available from: http://www galiciaclinica.info/PDF/11/225.pdf. Spanish.

19. Kefar-Saba I. Dooblo SurveyToGo software. Version 1.32.191.0 [Internet]. [place unknown]: Dooblo; 2014 [cited 2019 Feb 21]. Available from: https://www.dooblo.net/ 
20. Ministry of Health (CL). Estudio de verificación del costo esperado individual promedio por beneficiario del conjunto de problemas de salud con garantías explícitas-2015. Extracto capítulo beneficiarios, demanda y fichas técnicas [Internet]. Santiago de Chile: Ministry of Health (CL); 2017 [cite 2018 Jun 7]. Available from: http://desal .minsal.cl/wp-content/uploads/2017/10/deman da-selection-1-384.pdf. Spanish.

21. World Health Organization. Informe mundial sobre el envejecimiento y la salud [Internet]. Geneva: World Health Organization; 2015 [cited 2019 Feb 10]. 32 p. Available from: https://www .who.int/ageing/publications/world-report-2015/ es/. Spanish.

22. Paraje G, Vásquez F. Health equity in an unequal country: the use of medical services in Chile. Int $J$ Equity Health [Internet]. 2012:11:81. Available from: http://www.pubmedcentral.nih.gov/article render.fcgi?artid=3544610\&tool=pmcentrez\&ren dertype=abstract

23. Mortenson WB, Demers L, Fuhrer MJ, Jutai JW, Lenker J, DeRuyter F. Effects of an assistive technology intervention on older adults with disabilities and their informal caregivers an exploratory randomized controlled trial. Am J Phys Med Rehabil [Internet]. 2013 Apr [cited 2018 Jan 29];92(4):297-306. Available from: https://www ncbi.nlm.nih.gov/pmc/articles/PMC5484629/

24. Arthanat S, Bauer SM, Lenker JA, Nochajski SM, Wu YW. Conceptualization and measurement of assistive technology usability. Disabil Rehabil Assist Technol [Internet]. 2010 Aug 24 [cited 2015 Jan 29];2(4):235-48. Available from: http://informahealthcare.com/doi/ abs/10.1080/17483100701343665

25. Oztürk A, Simşek TT, Yümin ET, Sertel M, Yümin $M$. The relationship between physical, functional capacity and quality of life (QoL) among elderly people with a chronic disease. Arch Gerontol Geriatr [Internet]. 2011 Nov-Dec [cited 2015 Jan 29];53(3):278-83. Available from: http://www ncbi.nlm.nih.gov/pubmed/21215469

26. World Health Organizationd; USAID; Sociedad Internacional de Prostética y Ortótica. Pautas para el suministro de sillas de ruedas manuales en entornos de menores recursos [Internet]. Geneva: World Health Organziation; 2008 [cited 2019 Jan 20]. 141 p. Available from: https://www .who.int/publications/list/9789241547482/es/. Spanish.

27. Samuelsson K, Wressle E. User satisfaction with mobility assistive devices: an important element in the rehabilitation process. Disabil Rehabil [Internet]. 2008 [cited 2015 Jan 29];30(7):551-8 Available from: http://www.tandfonline.com/doi/ abs/10.1080/09638280701355777

28. Iñaki Martín L, López-Torres Hidalgo JD, Gorroñogoitia Iturbe A, Canto de-Hoyos Alonso M, Baena Díez JM, Herreros Herreros Y. Actividades preventivas en los mayores. Aten Primaria [Internet] 2014 [cited 2018 Jan 29];46(Suppl 4):75-81. Available from: https://www.elsevier.es/es-revista-aten cion-primaria-27-articulo-actividades-preventivas -los-mayores-actualizacion-S0212656718303652. Spanish.

29. Silva Fhon JR, Coelho Fabricio-Wehbe SC, Pereira Vendruscolo TR, Stackfleth R, Marques $S$, Partezani Rodrigues RA. Caídas en el adulto mayor y su relación con la capacidad funcional. Rev Lat Am Enfermagem [Internet]. 2012 SepOct [cited 2018 Jan 8];20(5). Available from: http://www.scielo.br/pdf/rlae/v20n5/es_15.pdf. Spanish.

30. González G, Marín PP, Pereira G. Características de las caídas en el adulto mayor que vive en la comunidad. Rev Méd Chile [Internet]. 2001 Sep [cited 2018 Aug 3];129(9):1021-30. Available from: http://www.scielo.cl/scielo.php?script=sci _arttext\&pid=S0034-98872001000900007\&lng =en\&nrm=iso\&tlng=en. Spanish.

31. Leving MT, Vegter RJK, De Groot S, Van der Woude LHV. Effects of variable practice on the motor learning outcomes in manual wheelchair propulsion. J Neuroeng Rehabil [Internet]. 2016 [cited 2018 Dec 7];13:100. Available from: http:// dx.doi.org/10.1186/s12984-016-0209-7

32. Sarigul-Klijn Y, Lobo-Prat J, Smith BW, Thayer $\mathrm{S}$, Zondervan $\mathrm{D}$, Chan V, et al. There is plenty of room for motor learning at the bottom of the Fugl-Meyer: Acquisition of a novel bimanual wheelchair skill after chronic stroke using an unmasking technology. IEEE Int Conf Rehabil Robot [Internet]. 2017 Jul [cited 2018 Dec 7]:2017:50-5. Available from: https://www.ncbi .nlm.nih.gov/pubmed/28813792

33. Jung K, Kim Y, Cha Y, In TS, Hur YG, Chung $Y$. Effects of gait training with a cane and an augmented pressure sensor for enhancement of weight bearing over the affected lower limb in patients with stroke: a randomized controlled pilot study. Clin Rehabil [Internet]. 2015 Feb [cited 2018 Dec 7];29(2):135-42. Available from: https://journals.sagepub.com/doi/ pdf/10.1177/0269215514540923

34. Ministry of Social Development (CL). Encuesta de Caracterización Socioeconómica Nacional - CASEN [Internet]. Santiago de Chile: Ministry of Social Development (CL); 2013 [cited 2018 Apr 5]. Available from: http://www.ministerio desarrollosocial.gob.cl/resultados-encuesta -casen-2013/. Spanish.

35. Pontificia Universidad Católica de Chile, Servicio Nacional del Adulto Mayor, y Caja Los Andes, Pontificia Universidad Católica de Chile, Servicio Nacional del Adulto Mayor y CLA. Chile y sus mayores. Resultados Tercera Encuesta Nacional de Calidad de Vida en la Vejez. [Internet]. Santiago de Chile: Pontificia Universidad Católica de Chile; 2013 [cited 2018 Mar 5]. Available from: http://www.senama.gob .cl/storage/docs/Resultados-Tercera-Encuesta -Nacional-Calidad-de-Vida-en-la-Vejez-2013 .pdf. Spanish.

36. Ministry of Social Development (CL). Política integral de envejecimiento positivo para Chile 2012-2025 [Internet]. Santiago de Chile: Ministry of Social Development (CL); 2012 [cited 2018 Apr 10]. Available from: https://vifadultomayor .files.wordpress.com/2016/12/senamalibropoliti cas .pdf. Spanish.

37. World Health Organization. Ciudades Globales Amigables con los mayores: Una Guía [Internet] Geneva: World Health Organization; 2007 [cited 2018 Apr 21]. 73 p. Available from: https://www. who.int/ageing/AFCSpanishfinal.pdf. Spanish.

38. Loredo-Figueroa MT, Gallegos-Torres RM, Xeque-Morales AS, Palomé-Vega G, Juárez-Lira A. Nivel de dependencia, autocuidado y calidad de vida del adulto mayor. Enferm Univ [Internet] 2016 Jul-Sep [cited 2018 Jul 5];13(3):159-65 Available from: http://linkinghub.elsevier.com/ retrieve/pii/S1665706316300197. Spanish.

39. Seoane $B$, de la Iglesia $F$, Nicolás $R$, Ramos V, Pellicer C, Diz-Lois F. Análisis factorial de la calidad de vida relacionada con la salud de pacientes que ingresan en una unidad de corta estancia médica. Rev Med Chil [Internet]. 2009 [cited 2018 Jul 5]:137(9):1163-72. Available from: https://scielo.conicyt.cl/pdf/rmc/v137n9/ art04.pdf. Spanish

40. Soberanes Fernández S, González Pedraza A, Moreno Castillo $\mathrm{Y}$ del $\mathrm{C}$. Funcionalidad en adultos mayores y su calidad de vida. Rev Espec Médico-Quirúrgicas [Internet]. 2009 [cited 2018 Jul 5];14(4):161-72. Available from: http://www .redalyc.org/pdf/473/47326415003.pdf. Spanish.

41. Lin S-I, Chang K-C, Lee H-C, Yang Y-C, Tsauo $\mathrm{J}$-Y. Problems and fall risk determinants of quality of life in older adults with increased risk of falling. Geriatr Gerontol Int [Internet]. 2015 [cited 2018 Jul 5];15(5):579-87. Available from: http://doi .wiley.com/10.1111/ggi.12320

42. Öztürk ZA, Özdemir S, Türkbeyler İH, Demir Z Quality of life and fall risk in frail hospitalized elderly patients. Turkish J Med Sci [Internet]. 2017 [cited 2018 Jul 5]:47:1377-83. Available from: http://online.journals.tubitak.gov.tr/openDoiPdf .htm?mKodu=sag-1610-107

43. Lobo A de JS, Santos L, Gomes S. Nível de dependência e qualidade de vida da população idosa. Rev Bras Enferm [Internet]. 2014 [cited 2018 Jul 5];67(6):913-9. Available from: http // www.scielo.org.mx/pdf/eu/v13n3/1665-7063 -eu-13-03-00159.pdf. Portugues.

44. Poblete-Valderrama F, Parra Cárdenas V, Salas Adasme D, Ayala García M, Cruzat Bravo E. Relación entre calidad de vida, equilibrio estático y dinámico en adultos mayores. Rev Peru [Internet]. 2017 Jun [cited 2018 Jul 5];4(2):471-7. Available from: http://www.rpcafd .com/2017_4_2/revista4(2)2017.pdf. Spanish.

45. Departament of Epidemiology. Ministry of Health (CL). Encuesta Nacional de Salud 2016-2017 [Internet]. Santiago de Chile: Ministry of Health (CL); 2018 Sep 21 [cited 2018 Oct 10]. Available from: http://epi.minsal.cl/encuesta-nacional-de -salud-2015-2016/. Spanish.

\section{THE AUTHORS}

Macarena Hirmas-Adauy (Corresponding author: mhirmas@udd.cl), midwife with a master's degree in public health, Epidemiology and Health Policy Center of the Medical School, Clínica Alemana, Universidad del Desarrollo (CEPS-CAS-UDD), Santiago, Chile.

Andrea Olea, surgeon with a master's degree in public health, CEPS-CAS-UDD, Santiago, Chile.

Isabel Matute, sociologist with a master's degree in public health, CEPS-CAS-UDD, Santiago, Chile.

Iris Delgado, biostatistician with a master's degree in biostatistics, CEPS-CAS-UDD, Santiago, Chile.

Ximena Aguilera, surgeon and public health specialist with a master's degree in public health, CEPS-CAS-UDD, Santiago, Chile.

Lucy Poffald, psychologist with a master's degree in psychology, CEPS-CAS-UDD, Santiago, Chile.

Claudia González, psychologist with a master's degree in public health, CEPS-CAS-UDD, Santiago, Chile.

Manuel Nájera, surgeon with a master's degree in epidemiology, CEPS-CAS-UDD, Santiago, Chile.

María Inés Gómez, surgeon and public health specialist, Padre Hurtado Hospital (HPH), Santiago, Chile.

Ligia Gallardo, Social Worker, HPH, Santiago, Chile.

María Teresa Abusleme, sociologist with a master's degree in political science, Department of Mental Health, Public Health Division, Ministry of Health, Santiago, Chile.

Jaime Leppe, kinesiologist with a master's degree in epidemiology, School of Kinesiology, CAS-UDD, Santiago, Chile.

Hernán Mery, occupational therapist, Rehabilitation and Disability Department, Ministry of Health, Santiago, Chile.

Eladio Recabarren, occupational therapist, Community Development Office, Cerro Navia Municipality, Santiago Chile.

Cristián Massad, sociologist, National Older Adult Services, Social Development Ministry, Santiago, Chile.

Hernán Bustamante, surgeon with a master's degree in business administration, HPH, Santiago, Chile.

Submitted: November 1, 2018

Approved: June 2, 2019

Disclosures: None 